\title{
Correction to: Absolute Pediatric Neurology
}

Yasser M. Awaad

\section{Correction to:}

Y. M. Awaad, Absolute Pediatric Neurology, https://doi.org/10.1007/978-3-319-78801-2

The author, Dr. Awaad's affiliation has been corrected as below:

Bloomfield Hills, MI

USA 